\title{
International trust and public diplomacy
}

\author{
Mogensen, Kirsten
}

Published in:

International Communication Gazette

DOI:

10.1177/1748048514568764

Publication date:

2015

Document Version

Peer reviewed version

Citation for published version (APA):

Mogensen, K. (2015). International trust and public diplomacy. International Communication Gazette, 77(4), 315336. https://doi.org/10.1177/1748048514568764

\section{General rights}

Copyright and moral rights for the publications made accessible in the public portal are retained by the authors and/or other copyright owners and it is a condition of accessing publications that users recognise and abide by the legal requirements associated with these rights.

- Users may download and print one copy of any publication from the public portal for the purpose of private study or research.

- You may not further distribute the material or use it for any profit-making activity or commercial gain.

- You may freely distribute the URL identifying the publication in the public portal.

\section{Take down policy}

If you believe that this document breaches copyright please contact rucforsk@kb.dk providing details, and we will remove access to the work immediately and investigate your claim. 


\begin{abstract}
NB: This is a pre-publication manuscript submitted to the journal on October 15, 2014. This manuscript was submitted after the first peer-review process. It was modified on January

7,2016 , so that it includes some corrections of misunderstandings that were located after submission but before printing. For the final version of the article, please consult the published version.
\end{abstract}

\title{
International Trust and
}

\section{Public Diplomacy}

\author{
Author: \\ Kirsten Mogensen
}

Contact details: Kirsten Mogensen, Roskilde Universitet, Universitetsvej 1, Hus 44.2, 4000 Roskilde Denmark. Email: kmo@ruc.dk

\section{Key-words}

British Council, Hassan Rouhani , international trust, people-to-people diplomacy, public diplomacy, strategic communication, trust building, US-Turkey relations, young filmmakers, Youth Innovation and Entrepreneurship Program. 


\begin{abstract}
National leaders struggle to communicate in ways that are perceived as trustworthy by citizens of other nations because trust is linked to efficiency, business opportunities, and political influence. In this article, four recent public diplomacy activities are analyzed from a trust-building perspective: Iranian President Hassan Rouhani's letter in The Washington Post; The British Council's strategy for trustbuilding in China; Russian President Vladimir V. Putin's letter in The New York Times; and the USA's trust-building effort in Turkey. The analyses are based on already publicized descriptions of public diplomacy activities, public polls, and scholarly literature. Public diplomacy ideas discussed include lightshow, hand-on cooperation, win-win projects, and the creation of frameworks for self-expression. A central concept is international trust as described by Brewer, Gross, Aday and Willnat. Based on the analysis it is suggested to amend the concept, to distinguish between trust in foreign people and trust in foreign governments.
\end{abstract}

Key words: strategic communication, international trust, public diplomacy, trust building, USTurkey relations, self-expression, Youth Innovation and Entrepreneurship Program, opinion leaders, people-to-people diplomacy, British Council. 


\section{Introduction}

During the last decade it has become common practice for national leaders to communicate directly to the public in other countries in order to gain trust. Well-known examples related to the Syrian civil war in the 2010s are Iranian President Hassan Rouhani’s opinion piece in The Washington Post (Rouhani, 2013) and Russian President Vladimir V. Putin’s op-ed in The New York Times (Putin, 2013). These are examples of national leaders trying to persuade the Western public to trust them and support their foreign policy during an international crisis that many feared could lead to a new world war.

The abovementioned examples of public diplomacy have been much debated around the world; however, on a smaller scale national leaders communicate directly with foreign publics every day in order to build trust over time. Such international communication has become easy, available, and affordable with the many free services provided by mobile technology and social media platforms. While the entry barriers to the international platforms are extremely low, the competition for attention is high, and the international audience is -- often for good reasons -skeptical. The high prize in the public diplomacy game is trust.

In the international arena, public trust is a treasure. Trusted leaders are welcomed around negotiation tables and as signatories on international agreements. Trust creates an atmosphere where other people are willing to cooperate, take risks, and contribute money. Research has shown that when citizens trust their international partners, they prefer diplomatic solutions to conflicts rather than military interventions (Brewer 2004; Sides and Gross, 2013), are more 
willing to support development and efforts to combat poverty (Brewer et al 2004: 106;

Hetherington, 2005; Kathrani, 2009), and are more prepared to engage in international institutions such as the Nuclear Non-Proliferation Treaty (Ruzicka and Wheeler, 2010: 70) and the International Criminal Court in the Hague (Kathrani, 2009).

Trust is often based on familiarity and previous experience (Luhmann, 1979: 18); however, trust can also be constructed despite unfamiliarity or even with a conflict-filled history (Hoffman, 2006a: 2). One way of doing it is through the creation of institutions (Hoffman ,2006a, 2006b; Zucker, 1985); another is through persuasive communication. An example of the latter was President Obama’s efforts to ‘strengthen international diplomacy and cooperation between peoples' that was awarded the Nobel Peace Prize 2009 (Nobelprize.org, 2009). At the time Obama had not demonstrated an ability to create peace, but the chairman of the Nobel Committee -- and soon after also secretary general of the Council of Europe -- Thorbjørn Jagland, explained that Obama with his communication on important international issues and by supporting international institutions like the UN contributed to an improved international climate and that the committee wanted to 'embrace the message that he stands for' (Gibbs, 2009). In the context 'an improved international climate' can also be described as a more trusting environment. Trust then was already created in the beginning of Obama's first presidential term, and with that international trust it was comparatively easier to maneuver on the international arena. Trust from this perspective is an 'independent, rather than dependent, variable' (Aday, 2005: 330).

However, it is always risky to trust. On the international arena this is demonstrated regularly when journalists make appointments with terrorists in order to cover their point of views only to be beheaded when they arrive at the agreed location. As Luhmann (1979: 33) wrote, it is 
pathological to trust if there is no ground for trust in the reality of the world. While citizens will argue that the journalists were naive in trusting the terrorists, countries face similar risks when they enter international agreements like the Nuclear Non-Proliferation Treaty. As an example, when countries refrain from obtaining nuclear weapons, they bring themselves in a vulnerable situation where they cannot defend themselves in case the nuclear nations break their promises not to use the weapons (Ruzicka and Wheeler, 2010: 69).

In the end, foreign policy is generally determined by the opinion of citizens (Lacina and Lee, 2013). And around the world citizens express little trust in political leaders, international institutions, and foreign countries (Hessami, 2011; Ipsos MORI, 2013; Poushter, 2013; World Economic Forum, 2012). This lack of trust is so serious that the World Economic Forum considers it one of the major risks in the years to come. With regard to the risk-situation in general, the World Economic Forum (2012: 49) in its conclusion writes:

Trust, or lack of trust, is perceived to be a crucial factor in how risks may manifest themselves. In particular, this refers to confidence, or lack thereof, in leaders, in the systems which ensure public safety and in the tools of communication that are revolutionizing how we share and digest information.

Trust is seen as a fundamental factor in the effort to handle risks and ensure public safety. The general trust in other people and public institutions that we refer to as social trust is important for a society to function. In a review of literature, Bakir and Barlow (2007: 13) summarize some of the benefits of social trust, including its ability to hold a society together; to facilitate business 
and other forms of exchange between citizens; to motivate people to engage in political life as well as to contribute to civil society; and to make it possible for democracies to function.

Trust is discussed in scholarly work on diplomacy and international relations, where it is often referred to as a risk-taking based on previous experience between nations and sometimes even personal relations between national leaders (Booth and Wheeler, 2008). Rengger (1997) points to the importance of practices that people can expect other to comply with, and that this 'propensity is rooted, in part, in a "presumption of trust." One of the reasons for the present focus on trust is that traditional diplomatic practices developed by states are outdated because there are many new and powerful actors in the global world, and new practices have not been developed and backed by power (Adler, 1997: 340). Power can, for example, be exercised in the form of 'international shaming,' honoring, and institutionalizing, as suggested by Rengger (1997: 486): ‘The crucial feature of this "shaming" practice is that it would need to be public.' According to Adler (1997: 334), progress is linked to 'universal normative ideas,' and it is based on what political actors actually do, as well as how they redefine their identities and interests. These perspectives are important when discussing the value of public diplomacy efforts in relation to the idea of international trust, such as the ones discussed later in this article.

\section{International trust}

Brewer, Gross, Aday, and Willnat (2004:96) conceptualized the term International Trust as a

generalized belief about whether most foreign countries behave in accordance with normative expectations regarding the conduct of nations. Citizens with high levels of international trust see the realm of world affairs as a friendly environment where trust and 
cooperation among nations are the norms; in contrast, citizens with low levels of international trust see the same realm as a hostile environment where all nations strive against one another for advantage and readily defect from cooperative efforts. Put another way, international trust is a standing decision to give other nations the benefit of the doubt, an assumption that most countries are of good will and benign intentions.

It is important to notice that trust here is linked to normative expectations and to conduct. In other words, trust from this perspective has to do with performance. Brewer et al. (2004: 99) used the following questions to measure general trust in other nations: 'Would you say that most of the time other nations try to be helpful to the United States or that they are just looking out for themselves?'

The norm as implied in the question is that other nations should be helpful to the USA. And the words 'most of the time' indicate that there are experiences to base trust on. In other words, trust from this perspective is linked to history. Respondents were not asked to distinguish between actors within these other nations. In another question, trust was seen as the negations of the need to be careful. In other words, it is really a question of whether we can relax in each other’s company or need to be on alert: 'Generally speaking, would you say that the United States can trust other nations or that the United States can't be too careful in dealing with other nations?'

These two questions relate to basic trust because they essentially ask people if they think that the United States can run the risk of being vulnerable or if other countries will misuse the vulnerability that comes with trust. The questions are similar to those used in other surveys about 
general distrust; they borrowed words from 'two of Rosenberg's (1956) misanthropy items' (Brewer, et al 2005: 41).

Among their American respondents Brewer et al (2004) noticed a pattern where 'generalized trust in other people and, to a lesser extent, generalized trust in government shaped international trust.' In other words, those Americans who generally believe in strangers also tend to trust foreigners more than do people who generally don't trust their fellow citizens. Similarly, if people trust their own government, they also tend to trust other nations' governments more than people who don't even trust their own government. Americans' level of international trust frame their perspectives on individual nations and have a huge impact on whether they see these foreign countries as friendly or as unfriendly. It is not known if citizens in other nations also express a higher level of international trust if they trust their fellow citizens and their politicians (Brewer, 2013, personal communication). There are obvious cases where citizens distrust their own government and trust another government more because some of these people flee their countries and seek asylum in countries they trust more. However, it makes sense if most people generalize from their experience with people and political leaders around them.

Referring to Hurwitz and Peffley (1987, 1990; Peffley and Hurwitz, 1992), Brewer et al (2004) accept the idea that citizens use 'information shortcuts' when they form opinions about complicated issues like foreign policy and other nations. Most people do not generally go searching for detailed information about other nations, but despite the lack of detailed information they create mental images of nations. They generally form seemingly rational opinions thanks to such shortcuts. That is not to say that people would not change their opinion if they obtained more information, but they live with this 'low-information rationality' (see also Popkin, 1991; Sniderman, Brody and Tetlock, 1991: 19). 
Emperors and other major rulers throughout history probably have worked strategically with the creation of international trust and distrust in their power struggles, but as an academic construct it is relatively new. We still don't know all the elements that contribute to international trust. However, we do know from research that while international trust is related to social trust and political trust, it also has its own track and is not just a byproduct of social trust and political trust. As an example, the level of international trust is also related to international events (Brewer et al, 2004: 96), changes in the international environment (Brewer et al, 2005: 40), and to the opinions expressed by the respondents' favored political candidates - also referred to as party loyalties (Brewer, 2004; Brewer et al, 2005: 48).

Because trust is recognized as a necessary precondition for peace and prosperity in the world (Hoffman, 2006a: 1; World Economic Forum, 2012), the level and foundation for trust in other nations and in the global community as a whole has been measured and discussed by many scholars over the past few decades. Trust in another nation has a lot to do with the perception of whether that other country can be considered a friend or an enemy and with how competent and powerful that nation is (for references, see Sides and Gross, 2013: 584). A number of factors have been mentioned as having an impact on trust in other countries, including media coverage (Seib, 2010; Sides and Gross, 2013: 585; Willnat et al, 2000, 2003); historical links, such as colonial ties (Goldsmith, 2012: 234; Lacina and Lee, 2013: 152); previous conflicts, e.g. , related to military interventions, violations of local expectations, and unequal status (Goldsmith and Harris, 2012: 234); shared norms and values that allow for identification (Goldsmith and Harris, 2012: 237; Lacina and Lee, 2013: 143); religion and type of government (Lacina and Lee, 2013: 143); tolerance and respect for differences (British Council, 2012); and credibility (Goldsmith and Horiuchi, 2009:873). Trust in the international community is also affected by the creation of 
institutions that support cooperation in a world where there are historical reasons for little or no basic trust, just as it happens on national level (Hoffman, 2006a: xi; Kathrani, 2009: 100; Ruzicka and Wheeler, 2010; Zucker, 1985:4). Trust in international institutions is determined partly by peoples’ opinions about globalization in general and also by a perception of whether or not there is a fair representation in the decision-making bodies (Goldsmith and Harris, 2012: 236; Hessami, 2011: 1; Soderberg, 2006: 239). Finally, international trust is related to the conditions in the general environment. When people experience a growing economy and reliable government administration, they are more willing to risk trusting (Aday, 2005: 331) than they are during crisis and when faced with a corrupt environment.

\section{Public diplomacy}

National governments striving for influence on the international arena can chose between different strategies. One is to frighten: Build and publicly display a strong army, preferably including nuclear weapons, and to behave in a cruel way. Fear has 'always been a traditional tactic of control by authoritarian regimes,' write Booth and Wheeler (2008: 269). A recent example of a successful attempt to create fear are the videos of executions and other brutalities that the terror movement ISIS has posted on YouTube (CNN, 2014).

Another strategy is to try to win the trust and support of people in other countries so that they perceive the country as friendly and its leadership as competent. While it is very tempting to rely on soft power (Nye, 2010), most countries spend money on hard power just in case the trust in other nations turns out to be unfounded. 
Public diplomacy is one way of producing international trust. For the purpose of this article I will use the definition provided by Seib (2013), so that I will talk about public diplomacy when national governments reach out to "global publics directly, rather than through their governments.” According to Cull (2009: 10), it consists of the following elements: listening, advocacy, cultural diplomacy, exchange programs, international broadcasting, and - as a parallel activity "which has to be administered beyond rigidly maintained firewall” - psychological warfare. Professionals talk about the new and old public diplomacy. In both cases, the overall aim is to manage the international environment, but while the old was built on targeted messages, the new public diplomacy focuses on relation building, and it involves relations building among citizens from different nations on a horizontal level. While practitioners of the old style of public diplomacy talk about a nation’s image and prestige in the global world, practitioners of the new style talk about nation branding and use perspectives learned from corporate branding and network theory (Cull, 2009: 14). Just as is the case in corporate branding and public relations, public diplomacy is only perceived as convincing and can only create soft power if the country behaves in accordance with what it says it does. As Cull (2009: 27) writes: 'History is full of examples of international actors who found the best PD to be no substitute for a bad policy.' However, when a country behaves in a productive way, public diplomacy is needed in order for it to become publicly known and thereby contribute to the nation's soft power.

Trust is a necessary element in a working relationship (Hoffman, 2006a: 2), but despite the obvious link between public diplomacy and trust building, few scholars have tried to measure the effect of public diplomacy initiatives on international trust or even discussed public diplomacy in terms of trust. A common way of measuring the effect of public diplomacy initiatives is to 
analyze media coverage of the events, but even though media coverage is assumed to have an impact on the public agenda, including attribute salience (McCombs et al, 1997), positive media coverage of public diplomacy events is not a guarantee for friendly opinions among the citizens, especially not if the media have low credibility or are read by a small elite, e.g. , Englishlanguage newspapers in countries where most people use a different language (Douglas, 2012). Public diplomacy practitioners also tend to use public opinion polls in planning and evaluation (Banks, 2011; Fouts, 2006; Memis, 2010; Steven, 2007).

Goldsmith and Huriuchi argue that the impact of foreign leaders’ public diplomacy efforts have a lot to do with credibility (2009: 865), and in the trust-literature, credibility is also usually considered one of several prerequisites for trust (Jackob, 2010; Vanacker and Belmas, 2009). Goldsmith and Huriuchi (2009) found support for their hypothesis that if a foreign leader is perceived as credible, then 'public diplomacy will have a net positive effect on foreign policy perceptions.' But, if the leader is seen as non-credible, the public diplomacy event might create 'backlash,' which means that public opinion will be more negative after the event 'than would otherwise have been the case.' Goldsmith and Huriuchi reached this conclusion after having studied data from 19 multinational opinion studies conducted by six organizations in 61 countries plus Hong Kong and Kosovo. They focused on changes in public opinion in connection with high-level visits by the USA president and other high-level government officials to foreign countries.

Building trust on the foundation of war and conflict is one of the main challenges in today's world, and many international institutions are created to support the process. Researchers have pointed to different approaches, all of which are being practiced these years, including building a global culture and morality (Kathrani, 2009) similar to how national cultures were constructed 
back in the past (Carey, 2002: 78); construction of shared norms and values (Lacina and Lee, 2013: 162) such as within the EU; changing the stereotypes of specific other nations and foreigners in general (Sides and Gross, 2013: 597), which require a change in media coverage and is related to a change in real-world behavior; and institutions that discourage nations from dominating one another and encourage cooperation (Hoffman, 2006a: xi).

\section{Case studies}

Four high-profile public diplomacy initiatives involving trust building were examined in the light of public opinion polls in order to get an improved understanding of the link between public diplomacy and international trust. In general the analyses are based on published texts and opinion data. The four cases are Iranian President Hassan Rouhani’s letter in The Washington Post (2013); the British Council's strategy for trust building in China (2012); Russian President Vladimir V. Putin's letter in The New York Times (2013), and the USA's trust building effort in Turkey (from 2006). These cases were chosen in order to show a varied selection of recent approaches from different parts of the world. At the same time, the number of available cases was limited because public diplomacy practitioners generally are very secretive about their trustbuilding strategies and successes. I will briefly discuss the first three cases and then turn my attention to the last one from which communication insights of general interest in relation to international trust building can be derived: 
Iran.

In September, 2013, newly elected Iranian President Hassan Rouhani appealed directly to the international public to trust him despite an ongoing conflict involving hard power like international sanctions and nuclear threats. At the time more than eight out of ten American people considered Iran unfriendly. In fact Iran was seen as the greatest enemy of the USA (Gallup, 2013). It soon became publicly known that backstage diplomats had created a framework for upcoming negotiations at an international level (Crowley 2013: 19). To create public support for that surprising turn of events, each of the two presidents needed to be perceived as trustworthy by the other's public. Within a couple of weeks this trust-building process included the letter from Rouhani in The Washington Post, speeches at the U.N. General Assembly and a friendly phone call between Obama and Rouhani. During the fall of 2013 the USA public's trust in Iran and its leaders increased slightly. By November, more than 3 out of 10 respondents in a Pew Research poll (2013c) said that they thought Iranian leaders were serious about addressing international concerns about their country's nuclear enrichment program, but in general people were still very skeptical (Frankovic, 2013b; Jagel, 2013a, 2013b).

\section{Britain.}

One of the big actors in the public diplomacy is the British Council that was founded in 1934. Essentially its purpose is to create relations between British citizens and people in other parts of the world, teach the English language, and help foreigners get a sense of life and culture in the 
United Kingdom (British Council, 2015a). The British Council empathizes that its activities contribute to the trust building between people in the UK and people around the world, and that this trust has both economic and political value. Memis, (2010: 294):

The British Council believes that cultural relations builds international trust and understanding, generates opportunities for individuals to fulfill their potential, and fosters the cooperation that contributes to a stable world. We are in the business of people-to-people and society-to-society relationships, e.g., the two-way exchange of knowledge and ideas between people in the UK and people of other cultures.

The organization runs projects in more than 100 countries, 'involves more than 12.5 million people directly, and reaches 580 million people through digital media, radio and television' (British Council, 2013c). An example of British Council's activities is the cultural program UK Now in China in 2012. According to British Council (2013b: 19), events were held in 29 cities in mainland China, Hong Kong, and Macau presenting almost 800 UK artists and performers. More than 4 million people attended these events, and they generated more than 6,000 pieces of media coverage. Data collected online by the research agency YouGov in 2010 showed that Chinese ages 16-34 were more interested in opportunities to work/do business with people in the UK if they had experienced a cultural activity with the UK (British Council, 2013b: 4).

Russia. 
The Russian president's letter to the American public in September of 2013 is an example of a public diplomacy initiative that created a backlash. Essentially Vladimir Putin warned that a military intervention in Syria could have terrible consequences for the world society. He wrote that his relationship with President Obama was marked by 'growing trust' and that if it was possible to avoid the use of force against Syria, it would 'improve the atmosphere in international affairs and strengthen mutual trust.' However, representatives from the two major political parties in the USA immediately reacted unfavorably (CBS News, 2013; Moody, 2013). While some of Putin's thoughts were shared by many Americans (Frankovic 2013a; Jordan 2013), the tone of the letter was interpreted as patronizing the American people and its president. He used the tool of 'shaming', but it didn't create trust among the US citizens. Interviews conducted later in the fall 2013 showed that the majority of Americans (54 percent) viewed Russia unfavorable compared to 43 percent the year before (Pew Research, 2013a: 35; Swift, 2013).

\section{USA's trust-building effort in Turkey}

The USA finds it of strategic importance to have a good relationship with the Turkish people. Turkey plays an important and growing strategic role in international politics for a number of reasons, including its mediating role between the Muslim world and the Western world; its geographic position between Europe and Asia; and its NATO membership. From a USA perspective, it threatens the Americans' 'ability to engage on a broad range of foreign policy priorities' if the Turks have a negative opinion about the country (McKay, 2012: 41). The 
relationship with Turkey has been problematic at least since the 1990-91 Gulf War because many Turks felt that the USA failed to support them in relation to a number of security/military policy issues. 'By the mid-1990s, many Turks saw the United States as a less-than-reliable ally' and there was a 'climate of mistrust' (Lesser, 2006: 84). Since 1994 the Turkish electorate moved 'as a bloc' to the right of the political spectrum and became more conservative (Yesilada and Noordijk, 2010: 24). Both countries are important economies, and the trade between them has been growing. By 2012, Turkey bought approximately 6 percent. of its imports from the USA (Global Edge, 2014).

Pew Global attitude polls (2013b) showed that 52 percent of Turks was favorable of the USA in 1999/2000, but this dropped steadily after September 11, 2001, to 9 percent in 2007. The American Embassy in Ankara was faced with the challenge of 'reversing the negative trends in public opinion.' Then-cultural affairs officer at the embassy, Elisabeth McKay (2012: 41), writes, 'Post took on the challenge of establishing a homegrown public diplomacy campaign to re-establish trust and open new avenues of engagement with a Turkish public that was measurably disinclined to engage with us.'

The strategy consisted of ten projects. Some key concepts were alternative audience (emphasis on Turkish youth; inclusion of audiences who would usually not benefit from USAsponsored programs because they did not speak English or lived in remote areas); people-topeople approach ('privatization' of the relationships between Turks and Americans); new image of the USA-Turkish relationship (show that a wide variety of relationships existed between people in the two countries - not only military/security); new media (social media included); and focus on topics of shared interest (education, culture, commerce). It is worth noticing that the 
strategy indirectly mediated liberal/USA values like entrepreneurship, free speech, critical thinking, diversity, and individualism.

In her article Recapturing the Narrative in Turkey, McKay (2012) discusses three of the projects: 1) Youth Innovation and Entrepreneurship Program; 2) Youth Filmmakers; 3) The Wiki. I will analyze each of these in the light of the theory presented above as well as the political and cultural context in which the communication took place.

Youth Innovation and Entrepreneurship Program (YIEP)

The Youth Innovation and Entrepreneurship Program 'brings classrooms in Turkey and the U.S. together to develop entrepreneurial projects’ (iEARN-USA, 2011). Turkish high school teachers were trained to coach students in the fundamental of business education and entrepreneurship, and students created their own school-based companies though which they gained insight into innovation, financing, marketing, trading, etc. High school teams competed, they shared ideas with American students online, and some of them participated in the Global Entrepreneurship Summit in Istanbul in 2011 (americaabroad, 2012).

The aim was to ‘promote entrepreneurship and innovative thinking,' writes McKay (2012: 44) and adds that 'encouraging critical analysis would not only be in the interest of the United States, it would also benefit future generations of Turks and give them important 21st century skills.'

Successful entrepreneurs are generally respected in both cultures, and the project seemingly launched at a time where there was an increased awareness about entrepreneurship in Turkey. Karadeniz (2011: 51): 
There has been recent and increasing emphasis on entrepreneurship in the media, with local newspapers, national papers and business magazines promoting and publicizing entrepreneurship. Experts also believe that starting up a new business is considered an appropriate way to become rich and that an entrepreneur is a desirable career. This positive attitude about entrepreneurship is very helpful for encouraging start-ups.

The cultures have different values related to entrepreneurship. In the USA, entrepreneurship, innovation, and creativity are celebrated values, and young entrepreneurs are told that 'learning to fall is an important part of learning to stand' (Ortmans, 2014). In Turkey, the culture does not encourage innovation, creativity, and risk-taking, according to an expert panel. Karadeniz (2011: 51) writes that 'Turkish people do not want to take a risk because failure is, for them, an unacceptable outcome.' Despite such lack of cultural encouragement, the expert panel found that Turks have a much more positive attitude to entrepreneurship than people in many other countries, and Turks were motivated to join the projects that also created opportunities for advanced education.

From the embassy perspective the project was a success. The students created innovative projects of which some were marketable, and it allowed for communication with students who had otherwise little direct exposure to Americans and did not know 'America beyond conventional stereotypes' (McKay, 2012: 44). On the Internet, students could find additional content and connect with students abroad. Rogler and Berrian (2014) write that the connection between students allow them to 'explore how innovation, entrepreneurism, culture, and their lives are similar and different in the two countries, enriching awareness, and understanding.' 
Building on-line person-to-person relationships between high school students across the Atlantic is complicated by a number of factors, including the time difference that makes it difficult to schedule online communication within class hours. Despite such challenges, the US embassy in Ankara continues to sponsor virtual classroom projects in cooperation with the Turkish Education Association (PH International, 2014).

\section{Youth Filmmakers}

This project helped young people create films. McKay (2012: 45): ‘Turkish youth, like youth elsewhere, want to be heard. The filmmakers' project gave them an opportunity to convey their views on an international stage on issues they cared about. It gave us a vehicle for promoting linkages, and encouraging critical thinking and freedom of expression.'

The 72 selected participants from six different parts of Turkey 'were asked to create films about important issues in their communities’ (McKay, 2012: 46). At the website www.filmturkey.net are pictures of the students in action as filmmakers and links to the resulting 18 short films with English subtitles. The content on the website is treasure chest for anyone truly interested in understanding the existential problems with which young Turks are dealing. Many of the scenes are shot close-up, allowing the viewer to be emotionally touched. For illustration, I randomly selected three of these short films: 1) Spring; 2) When the Plum Trees Bloom; 3) 15 Steps Ahead. Spring is a documentary filmed during the celebrations of the coming of spring in a Romani neighborhood in Edirne. Footage of people dancing, singing, and playing games are mixed with Romanis talking about unemployment, racism, teen pregnancy, betrayal, parents, and romantic dreams of marriage. When Plum Trees Bloom follows a young rebel who 
chooses between love for a woman and fighting the military coup plotters of 1980. Eventually he is hanged, but his final love letter is brought to the young woman. 15 Steps Ahead follows two female candidates running for office in an all-male political environment in Sivas and includes statements from both men and female, old and young -- most of them expressing the opinion that women should stay at home and leave public offices to men.

Public diplomacy officers worked with Istanbul's Atlantik Film and New York's state university Fredonia to provide film training and project management. Some of the participants were selected for a brief internship in New York, where they worked with American students. According to McKay, the project created extensive media coverage, partly because one of project directors was the much-celebrated Turkish documentary filmmaker Nefin Dinç. Project films were screened at more than 60 festivals in Europe and the USA.

Another reason for the success of the film project may be that the film industries in the USA and Turkey have a long shared history, so this film-related freedom of expression program did not create the suspicion that similar projects might have done in other countries. In short, Turkey has for decades welcomed Hollywood movies (Sari Karademir, 2012) and American Studies programs (Pakin, 2008). Sari Karademir (2012: 635) writes about the political sentiment in Turkey in the years after World War II that the ‘US was an attractive model for Turkey's ongoing project of modernization and Westernization [--] The US became so attractive to Turkish politicians that transforming Turkey into a "little America" became non-partisan state promise.'

In her article with the headline Turkey as a 'Willing Receiver' of American Soft Power: Hollywood Movies in Turkey during the Cold War Sari Karademir (2012) writes that Soviet films were banned during the Cold War because they were perceived as ideological while American 
films were welcomed and United States Information Service supported distribution of movies that contributed to construction of the preferred image of American lifestyle. Also, many Turkish films produced during the Cold War adopted the American movie style and storylines. Pakin (2008) writes that American Culture and Literature departments have been 'flourishing in Turkey' and that in the 1980s Turkey had 'a newly rich class almost obsessed with the American lifestyle.’

It is worth noticing that, according to the 2010 Inglehart-Welzel Cultural Map of the World, people in the USA and Turkey are on the same level when it comes to traditional values, such as importance of religion, traditional family values, national pride, and deference to authority (World Values Survey, 2014). For example, a 2012 survey found that 85 percent of Turks and 84 percent of Americans had favorable views of their own country (Daily News, 2012).

Where they differ, according to that map, is on the dimension of survival values vs. selfexpression values. In general, Turks lean more toward the survival -- with emphasis on economic and physical security -- while North Americans lean more toward self-expression. According to World Values Survey (2014), survival values are often linked with 'a relatively ethnocentric outlook and low levels of trust and tolerance.' People in both countries find religion very important, but while 8 out of 10 US citizens accept other religions, 8 out of 10 Turks do not. The film project aimed at increasing self-expressions by the young Turks could theoretically increase trust in and tolerance of foreigners. I will discuss that later.

The Wiki 
In 2007, the US embassy created an online platform aiming at connecting Turkish and American youth. As with many similar platforms created by embassies, it contained information about opportunities for scholarships, exchange programs, cultural events, etc. The embassy hoped that youths on both sides of the Atlantic would use the platform for a broader exchange of opinions and ideas; however, it was not a success, partly because there are many competing communication platforms on the market and partly because it was not created as a solution to problems experienced by youths. McKay (2012: 48) writes that they 'built a goal-oriented site maintained by us rather than a true communication platform maintained by our target audience. Monitored communication was also a deterrent as users felt reluctant to be open about their opinions.’

Today the US embassy in Turkey uses Facebook, Twitter, and YouTube very similarly to other embassies.

Trust polls in the USA--Turkey case

Because trust in foreign countries is determined by many factors, the effect of three programs on the general public opinion is not known.

A Pew Global Attitude Survey (Pew Research 2014) showed that 19 percent of the Turks had a favorable view of the USA, compared to 9 percent in 2007, but despite the increase, another PEW Research poll (2013b) showed that 75 percent of Turks still did not believe that USA consider their interests at all.

According to Transatlantic Trends (2014), 7 out of ten Turks did not want a strong USA, Chinese or Russian leadership in international affairs, but while they did not want strong nations 
to lead the world, they were slightly more positive towards the countries as such. 64 percent of the Turks expressed unfavorable views of the USA, while 68 percent had unfavorable views of China and Russia.

In relation to trust, the World Values Surveys 2005-09 and 2010-14 point to a very interesting development. It seems like an increasing number of citizens consider themselves as world citizens --- out of ten it is now nearly 9 Turks and 7 US citizens. General trust has increased among Turks but dropped among Americans in the 2010s. Asked whether most people can be trusted, nearly 12 percent (up from 5) of the Turks and 35 percent (down from 39) of US citizens said yes in the survey.

\section{Discussion and hypothesis}

According to the literature, peoples' trust in other countries -- their people and their governments -- is closely related to how people trust their own neighbors, government, and media; how safe they feel; and what kind of picture their opinion leaders present of the world. Peoples’ international trust influences how they perceive single countries. Most people do not have the time, the means, or the interest in more in-depth studies of the many different countries in the world, so they rely on shortcuts in their judgments. Surveys indicate that perceptions of other countries generally stay at the same level for decades unless a real event has a serious impact; negative events typically have a quicker impact on the trust-level than positive events. It is so much easier to break trust than to build it. 
However, international trust is important for the global world to be peaceful and prosperous. International organizations try to create trust and so do a number of individual countries that consider trust a value in business as well as politics. What they seek is to influence the shortcuts, but how they can best influence those is still an open question.

Some lessons have been learned from the public diplomacy cases analyzed in this article, and I will discuss four of them as hypotheses that ought to be further explored because they can contribute to our theories about international trust building and public diplomacy.

\section{Lightshow}

The US-Turkey case is interesting because it allows us to explore the different contexts in which related strategic tools, such as agenda setting, reframing, and attraction, are useful in practice. Communicators attract attention by highlighting. The metaphor of light has a long history in public relations. For example, Stoker and Rawlins (2005: 177) use the metaphor of light to describe how public relations developed as an institution in the 1920s:

In less than thirty years, the definition of publicity had changed from a broad searchlight for exposing excess and corruption to a controlled flashlight illuminating only those practices that corporations wanted the public to see. Just as the surrounding area becomes darker as the eye adjusts to the narrow target of a flashlight's beam, the new profession of public relations transformed publicity into a strategic weapon for deflecting public scrutiny away from some business practices while calling attention to more favorable actions. 
The embassy in Ankara faced a situation where there was already a powerful flashlight pointing to national security and NATO policy. This is the sphere of negative emotions, such as distrust, fear, and anger. To create a world free from security risks or transform the justified emotions related to them are not within the power of any public diplomacy staff. Neither is it possible for them to close the flashlight that point to these threats because issues related to personal security are of outmost concern to humans all over the world. Such issues must be dealt with appropriately, using arguments as Presidents Putin and Rouhani attempted with their letters. No doubt, messages from heads of states to the international public are part of the political agenda-setting in the $21^{\text {st }}$ century, and so are efforts to reframe the central issues. Agenda-setting and framing relate to such important issues.

However, public diplomacy can also be used to illuminate good stories that are otherwise hidden in the dark. Stroker and Rawlins write about one flashlight. I will introduce the term lightshow for situations where communicators consciously illuminate areas of the dark by bringing in more flashlights.

Especially in times of crisis and distrust, good stories are helpful because negative emotions can be overwhelming. For the same reason, journalists look for good stories of light when they cover disasters. Correspondent Don Dahler, ABC News, explained (Mogensen, 2008: 42):

You're walking through a darkened street, and there's a house with the light on. That's what you notice. So you might say there are other things going on in the dark, but what catches your attention and what focuses you is that light in that house. 
Professional ethics does not allow journalists to be pro-active in creating the good stories, but nothing within the norms of public diplomacy prohibits them from creating mutual beneficial projects and bringing in more flashlights that can illuminate them.

\section{Hands-on cooperation.}

In post-material societies many people want to link with foreigners who share their interests. Such transnational bonding can contribute to international trust because when participants are working together, creating, and finding solutions, they learn when to trust and not. With increased knowledge citizens can feel more confident in their own expectations (Luhmann, 1979).

To be successful, projects must be designed with the audiences' needs in mind (McKay, 2012), and based on genuine mutual interests among actors --- beyond feeling-good related charity and political advocacy. Such interests can include development of a market for export of goods, educational opportunities, and other forms of exchange. From this perspective, the Youth Innovation and Entrepreneurship Program was a win-win --- both parties had an economic interest in it. For example, USA had an economic interest in promoting its computer industry among Turkish youths while Turkey had an interest in computer training for high school students so that they could contribute to the nation's fast-growing economy.

Since the early days, public relations practitioners have understood the power of opinion leaders in campaigns. For a public diplomacy activity to succeed, it is paramount to link with respected local people. From a strategic communication perspective, the partnership with high 
school teachers is a key element in the US-Turkey case because teachers are respected in their communities and have a major impact on the students. High school teachers outside large cities may be more motivated to join because they do not have as many alternative opportunities for international cooperation as teachers in the large cities.

Also, for credibility reasons it might be worth considering the shared history and values when choosing projects, such as was the case in the Young Filmmakers project.

\section{Self-expression}

An interesting hypothesis emerges when the Youth Filmmaker project is evaluated in the light of World Values data: Maybe helping people to express themselves peacefully can create a short way to international trust, because people with self-expression values tend to be relative more tolerant and trusting in relationship with foreigners. Delhey and Welzel (2012) analyzed data from World Values Survey and concluded that 'trust generalizes to out-groups as a result of modernity’s emancipative impulses' and that 'a society’s out-group-trust extends beyond the level projected by in-group-trust when human empowerment diminished people’s dependence on in-groups and opens them to corporation with out-group.’

If this is true not only on a statistical level but also in experience across culture, international trust might not depend so much on shared religion, political view, or lifestyle, but instead on a shared appreciation of individuals' right to express themselves in peaceful ways.

\section{The concept of international trust}


It is useful to have a concept like international trust which is based on the assumption that people don't know much about most other countries and therefore to some extend project trust from their closer environment to the international community and use shortcuts in their trust evaluations.

However, the theory, cases and data examined in this article suggest that when talking about international trust we need to separate between peoples trust in foreign governments and their trust in foreign people, as also suggested by Brewer et al. (2004: 106). Some polls already separate between the two, and the data shows, that some respondents trust foreign people more than they trust foreign governments. It may be that what we at the moment register as a decrease in trust towards political, economic and religious authorities mark that we are indeed at the end of an era in which authorities were trusted by the majority, but that it is not the end of international trust.

Contrary to the predominantly pessimistic perception on the state of international trust, puzzle pieces from theory and cases presented in this article suggest that we are in the middle of a transformation which will eventually unfold as an increased trust in and tolerance of other people despite their differences.

For public diplomacy practitioners it is strategically important to know if their activities are aimed at increasing trust in their national authorities --- such as the letters from Putin and Rouhani --- or they are aimed at increasing trust between the general populations of two or more countries, such as the British and the US-Turkey projects examined in this article.

\section{Note}


I want to thank the two anonymous reviewers for their constructive suggestions, and Ronald L. Snipes for editing the manuscript. This article is a completely revised version of papers presented to the Nordic Research Network on Trust Within and Between Organizations in Skodsborg, Denmark, and to the AEJMC in Montreal, 2014, and I am grateful to all the reviewers involved in the process.

\section{References}

Aday S (2005) Why Trust Matters: Declining Political Trust and the Demise of American Liberalism. Public Opinion Quarterly 69(2): 330-332.

Adler E (1997) Seizing the Middle Ground: Constructivism in World Politics. European Journal of International Relations 3(3): 319-363.

americaabroad (2012) Global Entrepreneurship Summit in Istanbul, Turkey.

Bakir V and Barlow DM (2007) Communication in the Age of Suspicion: Trust and the Media. New York: Palgrave Macmillan.

Banks R (2011) A Resource Guide to Public diplomacy Evaluation. Los Angeles, USA: Figueroa Press.

Booth K and Wheeler NJ (2008) The Security Dilemma: Fear, Cooperation and Trust in World Politics. New York: Palgrave Macmillan.

Brewer PR (2004) Public Trust in (or cynicism about) Other Nations Across Time. Political Behavior 26(4): 317-317-341. 
Brewer PR, Aday S and Gross K (2005) Do Americans Trust Other Nations? A Panel Study. Social Science Quarterly (Wiley-Blackwell) 86(1): 36-51.

Brewer PR, Gross K, Aday S and Willnat L (2004) International Trust and Public Opinion About World Affairs. American Journal of Political Science 48(1): 93-109.

British Council (2015a, 2013a) Our Status.

British Council (2013b) Culture Means Business: How International Cultural Relationships Contribute to Increased Trade and Competitiveness for the UK. http://www.Britishcouncil.org/sites/britishcouncil.uk2/files/culture-Means-BusinessReport.Pdf. United Kingdom: British Council.

British Council (2013c) Contribution to UK Soft Power.

British Council (2012) Trust Pays: How International Cultural Relationships Build Trust in the UK and Underpin the Success of the UK Economy (Http://www.Britishcouncil.org/sites/britishcouncil.uk2/files/trust-Pays-Report.Pdf). United Kingdom: British Council.

Carey JW (2002) American Journalism on, before and after September 11. In: Zelizer B and Allan S (eds) Journalism After September 11. New York: Routledge, 71-71-90.

CBS News (2013) Selling the Message: How PR Firm Helped.

CNN (2014) ISIS Militants Posts New Execution Video.

Crowley M (2013) Obama's Iran Gamle. London: Time Magazines Europe.

Cull NJ (2009) Public diplomacy: Lesons from the Past. CPD Perspectives on Public diplomacy.

Los Angeles, USA: Figueroa Press.

Daily News (2012)

Turkey Favorable for Turkish People Only. 
Delhey J and Welzel C (2012) Generating Trust: How Outgroup-Trust Grows Beyond IngroupTrust.

Douglas W (2012) The last Three Feet: Understanding What Pakistanis Are Saying. In: Kiehl WP (ed) The Last Three Feet: Case Studies in Public diplomacy. Washington DC, USA: The Public diplomacy Council, 108-108-116.

Fouts JS (2006) Public diplomacy Practitioners, Policy Makers, and Public Opinion. Los Angeles, USA: USC Center on Public diplomacy, University of Southern California.

Frankovic K (2013b) Syria: Little Trust in Russia, no Desire for Force.

Frankovic K (2013a) Little Trust in Iran, More Support for an Aggressive Negotiating Strategy. Gallup (2013) Hot Topics: Iran.

Gibbs W (2009) From 205 Names, Panel Chose the Most Visible. The New York Times, October 10, 2009, p. A10.

Global Edge (2014) Turkey: Trade Statistics.

Goldsmith A and Harris V (2012) Trust, trustworthiness and trust-building in international policing missions. Australian and New Zealand Journal of Criminology (Sage Publications Ltd.) 45(2): 231-254.

Goldsmith BE and Horiuchi Y (2009) Spinning the Globe? U.S. Public diplomacy and Foreign Public Opinion. Journal of Politics 71(3): 863-875.

Hessami Z (2011) What Determines Trust in International Organizations? an Empirical Analysis for the IMF, the World Bank, and the WTO. Munich Personal RePEc Archive, Paper no. 34550. Munich, Germany: Munich University Library.

Hetherington M (2005) Why Trust Matters: Declining Political Trust and the Demise of American Liberalism. Princeton, USA: Princeton University Press. 
Hoffman A (2006a) Building Trust: Overcoming Suspicion in International Conflict. Albany, USA: State University of New York.

Hoffman AM (2006b) Building Trust: Overcoming Suspicion in International Conflict. Journal of Palestine Studies XXXVI(3): xiii; 111-112.

Hurwitz J and Peffley M (1990) Public Images of the Soviet Union: The Impact on Foreign Policy Attitudes. Journal of Politics 52(1): 3-3-28.

Hurwitz J and Peffley M (1987) How are Foreign Policy Attitudes Structured? A Hierarchical Model. American Political Science Review 81: 1099-1099-1120.

iEarn-USA (2011) Turkish Exchange Group Arrives in Oroville, Washington. Ipsos MORI (2013) Politician Trusted Less than Estate Agents, Bankers and Journalists.

Jackob NGE (2010) No Alternatives? The Relationship between Perceived Media Dependency, Use of Alternative Information Sources, and General Trust in Mass Media. International Journal of Communication (19328036) 4: 589-606.

Jagel K (2013b) Americans Pessimistic Over Interim Deal with Iran. Jagel K (2013a) Poll Results: Iran.

Jordan W (2013) Brits and Americans Agree: Putin had the Edge on Syria.

Karadeniz E (2011) Entrepreneurship in Turkey 2010: The Global Entrepreneurship Monitor (GEM). London, UK: Global Entrepreneurship Monitor, London.

Kathrani P (2009) A Decade of Change: a Case for Global Morality, Dialogue and Transnational Trust-Building. Jurisprudencija 4(118): 97-104.

Lacina B and Lee C (2013) Culture Clash or Democratic peace?: Results of a Survey Experiment on the Effect of Religious Culture and Regime Type on Foreign Policy Opinion Formation. Foreign Policy Analyses 9: 143-170. 
Lesser IO (2006)

Turkey, the United States and the Delusion of Geopolitics. Survival, the International Institute for Strategic Studies 48(3): 83-83-96.

Luhmann N (1979) Trust and Power: Two Works by Niklas Luhmann. with Introduction by Gianfranco Poggi. Chichester, Great Britain: John Wiley and Son.

McCombs M, Llamas JP, Lopez-Escobar E and Rey F (1997) Candidate Images in Spanish Elections: Second-Level Agenda-Setting Effects. Journalism and Mass Communication Quarterly 74(4): 703-717.

McKay E (2012) Recapturing the Narrative in Turkey. In: Kiehl WP (ed) The Last Three Feet: Case Studies in Public diplomacy. Washington D. C., USA: The Public diplomacy Council, 40-40-53. Memis S (2010) The Impact of International Cultural Engagement: The British Council's Approach to Evaluation. Journal of Arts Management, Law and Society 39(4): 292-297.

Mogensen K (2008) Journalism during terror attacks. Media, War and Conflict, Vol.1 (1): 31-49.

Los Angeles, London, New Delhi and Singapore: Sage. 1(1): 31-31-49.

Moody C (2013) U.S. Lawmakers Unite in Fury Over Putin's Op-Ed in New York Times.

Nobelprize.org (2009) The Nobel Peace Prize 2009.

Nye JSJ (2010) Soft Power and Cultural Diplomacu.

Ortmans J (2014) Succeeding through Failure. http://www.entrepreneurship.org/policyforum/succeeding-through-failure.aspx: Ewing Marion Kauffman Foundation.

PAKIN E (2008) American Studies in Turkey during the ‘Cultural’ Cold War. Turkish Studies 9(3): 507-524.

Peffley M and Hurwitz J (1992) International Events and Foreign Policy Beliefs: Public Responses to Changing Soviet-U.S. Relations. American Journal of Political Science 36(2): 431-431-461. 
Pew Research (2014) U.S. and EU Image Negative in Turkey.

Pew Research (2013a) Public Sees U.S. Power Declining as Support for Global Engagement Slips America’s Place in the World 2013: Complete Report. http://www.peoplepress.org/2013/12/03/public-sees-u-s-power-declining-as-support-for-global-engagement-slips/: Pew Research Center, Washington DC, USA.

Pew Research (2013b) Global Attitudes Project: Chapter 1. Attitudes Toward the United States. Pew Research (2013c) Public Sees U.S. Power Decline as Support for Global Engagement Slips: Americas Place in the World 2013.

PH International (2014) Virtual Classroom Project.

Popkin S (1991) The Reasoning Voter. Chicago: Chicago University Press.

Poushter J (2013) Global Public Opinion of Iran Remains Decidedly Negative.

Putin V (2013) A Plea for Caution from Russia.

Rengger N (1997) The Ethics of Trust in World Politics. : Wiley-Blackwell.

Rogler H and Berrian R (2014) Virtual Classroom Project and YIEP.

Rouhani H (2013) Why Irak Seeks Constructive Engagement (Published in the Printed Version September 19).

Ruzicka J and Wheeler NJ (2010) The puzzle of trusting relationships in the Nuclear NonProliferation Treaty. International Affairs 86(1): 69-85.

Sari Karademir B (2012) Turkey as a ‘Willing Receiver’ of American Soft Power: Hollywood Movies in Turkey during the Cold War. Turkish Studies 13(4): 633-645.

Seib P (2013) Public diplomacy and the Middle East. CPD Perspectives on Public diplomacy, Paper 6. Los Angeles, USA: Figueroa Press. 
Seib P (2010) Transnational Journalism, Public diplomacy, and Virtual States. Journalism Studies 11(5): 734-734-744.

Sides J and Gross K (2013) Stereotypes of Muslims and Support for the War on Terror. Journal of Politics 75(3): 583-598.

Sniderman PM, Brody RA and Tetlock PE (1991) Reasoning and Choise: Explorations in Political Psychology. New York: Cambridge University Press.

Soderberg NE (2006) The Crisis of Global Trust and the Failure of the 2005 World Summit. Ethics and International Affairs (Wiley-Blackwell) 20(2): 235-240.

Steven D (2007) Evaluation and the New Public diplomacy. Dorset, Great Britain: River Path Associates.

Stoker K and Rawlins BL (2005) The 'Light' of Publicity in the Progressive Era From Searchlight to Flashlight. Journalism History 30(4): 177-188.

Swift A (2013) For First Time, Americans' Views of Russia Turn Negative: Despite Approval of Russian Plan for Syria, Americans Sour on Putin.

Transatlantic Trends (2014) Country Profiles: Turkey 2014.

Vanacker B and Belmas G (2009) Trust and the Economics of News. Journal of Mass Media Ethics 24(2): 110-126.

Willnat L, Graf J and Brewer PR (2000) Priming International Affairs: How the Media Influence Attitudes Toward Foreign Countries.

Willnat L, Aday S, Brewer P and Gross K (2003) The Impact of Media on Perceptions of Foreign Nations and Foreign Policy Preferences. : International Communication Association. World Economic Forum (2012) Insight Report: Global Risks 2012 Seventh Edition. Cologny/Geneva Switzerland: World Economic Forum. 
World Values Survey (2014) Findings and Insights, Plus Online Data Analysis.

Yesilada BA and Noordijk P (2010) Changing Values in Turkey: Religiosity and Tolerance in Comparative Perspective. Turkish Studies 11(1): 9-27.

Zucker LG (1985) Production of Trust: Institutional Sources of Economi Structure, 1840-1920. Working Paper Series 82. Los Angeles, USA: Department of Sociology, University of California. 